\title{
FANTASTYKA, GROZA, PANESTETYZM I ANTYESTETYZM W POGLAॄDACH I TWÓRCZOŚCI HOWARDA PHILLIPSA LOVECRAFTA
}

Słowa kluczowe: fantastyka, groza, panestetyzm, antyestetyzm, Howard Phillips Lovecraft

Niniejszy artykuł ma na celu scharakteryzowanie poglądów, jakie reprezentował żyjący na przełomie XIX i XX w. amerykański pisarz Howard P. Lovecraft, zwłaszcza w dziedzinie literatury, przede wszystkim fantastycznej, oraz sposobów budowania nastroju grozy, które realizował w swoim warsztacie literackim. Ponadto poruszone zostaną zagadnienia panestetyzmu i antyestetyzmu obecnego u tego autora.

Za podstawę źródłową posłużyły listy i eseje Lovecrafta, które ukazały się nakładem krakowskiego wydawnictwa Sine Qua Non w tłumaczeniu Mateusza Kopacza ${ }^{1}$.

\section{FANTASTYKA I JEJ PODGATUNKI}

Dla pełnego zrozumienia omawianych kwestii należy wyjaśnić znaczenie terminów fantastyka i horror. Według Andrzeja Kaliszewskiego fantastyka literacka to „typ twórczości, w którym świat przedstawiony [...] nie odpowiada rzeczywistości, występują wątki i postaci nadnaturalne, ale wszystko to jest budowane w konwencji quasi-realistycznej, jakby z założeniem, że ma byt realny"2.

W Slowniku terminów literackich Michał Głowiński dodaje, że fantastyka wiąże się z postawą czytelnika, który zakłada, że to, co fantastyczne, istnieje, choć ma wątpliwości w kwestii rzeczywistego charakteru opowiadanych wydarzeń. Skutkuje to identyfikowaniem się czytającego z bohaterem - zwykłym człowiekiem osadzonym w świecie cudowności. W fantastyce, według Głowińskiego,

${ }^{1}$ H.P. Lovecraft, Koszmary i fantazje. Listy i eseje, przeł. M. Kopacz, Kraków 2013.

2 A. Kaliszewski, Gtówne nurty w kulturze XX i XXI wieku. Podręcznik dla studentów dziennikarstwa i komunikacji społecznej, Warszawa 2012, s. 55. 
wykorzystuje się motywy zaczerpnięte $\mathrm{z}$ dawnych tradycji, folkloru, wierzeń i mitów, a następnie układa się je w zamkniętą konstrukcję z zachowaniem ciagu przyczynowo-skutkowego. Co warte podkreślenia, w swojej definicji fantastyki z 1976 r. Głowiński powołuje się na esej Lovecrfata Nadprzyrodzona groza w literaturze

Najczęściej za odmiany fantastyki uznaje się: fantastykę naukową (science fiction), fantasy i horror. Podział ten nie jest jednak ścisły. Podgatunki te przeplatają się, poszczególni autorzy i ich dzieła zaliczani są do różnych z nich, a także do jeszcze kolejnych podgatunków. Samego Lovecrafta uważa się m.in. za przedstawiciela podgatunku o nazwie weird fiction, który utożsamiany jest niekiedy z horrorem.

Według Andrzeja Kaliszewskiego horror to „utwór, którego fabuła i postacie planowo wzbudzają przerażenie. Występują w nim zjawiska irracjonalne, makabryczne, magiczne, satanistyczne. Bohaterami są demony, duchy, wampiry, potwory, mutanty itp." ${ }^{4}$.

Jako inspiracje dla horroru w Stowniku nowych gatunków i zjawisk literackich Paulina Potrykus-Woźniak wymienia: śmierć, obawę przed umieraniem oraz ucieczkę od przemijania, jako źródło zaś - kulty i wierzenia religijne. Autorka przywołuje, że jednym z powodów zainteresowania horrorem jest nie tylko motyw przedstawienia strachu, ale też zdystansowanie się od niego. Zaznacza jednak, że horror nie zawsze spełnia tę funkcję, a często przynosi skutek wręcz odwrotny, tj. utożsamienie się odbiorcy ze strachem 5 .

Jak zauważa Potrykus-Woźniak, terminem horror początkowo określano wyłącznie filmy, a dopiero później, za sprawą tzw. magazynów pulpowych i czasopism literackich publikujących opowiadania o tej tematyce, pojęcie to objęło również literaturę ${ }^{6}$. Jednym $\mathrm{z}$ takich magazynów pulpowych był wydawany od lat dwudziestych XX w. „Weird Tales”, na łamach którego publikował również Lovecraft.

Nie istnieje jedna powszechnie uznana definicja weird fiction. Do popularyzacji tego terminu przyczyniło się wspomniane czasopismo „Weird Tales”, a także sam Lovecraft, który używał go w swoich esejach. Charakteryzując opowieść w konwencji weird, Lovecraft pisze:

Musi być w niej obecna atmosfera paraliżującego i niewytłumaczalnego zagrożenia ze strony pozaziemskich nieznanych sił; musi ona też podsuwać - i wyrażać ją w stosownie poważny i złowieszczy sposób - najstraszniejszą koncepcję, jaka tylko może się zrodzić w ludzkim

${ }^{3}$ M. Głowiński, Fantastyka, [w:] Słownik terminów literackich, red. J. Sławiński, Wrocław 1976, s. 116-117. Por. H.P. Lovecraft, Nadprzyrodzona groza w literaturze, [w:] idem, Przyszła na Sarnath zagłada. Opowieści niesamowite i fantastyczne, wybór, przekład, opracowanie i posłowie M. Płaza, Poznań 2016, s. 493-579.

${ }^{4}$ A. Kaliszewski, op. cit., s. 57.

${ }^{5}$ P. Potrykus-Woźniak, Słownik nowych gatunków i zjawisk literackich, Warszawa-Bielsko-Biała 2010, s. 77-78.

${ }^{6}$ Ibidem, s. 78. 
umyśle, że oto w osobliwy i złośliwy sposób zostały zawieszone bądź pogwałcone ustalone prawa Natury, stanowiące naszą jedyną ostoję w obliczu szturmów chaosu i demonów z niezgłębionej przestrzeni ${ }^{7}$.

Powyższa myśl skłoniła autora niniejszego artykułu do przyjrzenia się poglądom i twórczości Lovecrafta pod kątem koncepcji pan- i antyestetycznych oraz do próby odpowiedzi na pytanie, czy pisarz był bardziej panesteta, czy antyesteta.

\section{PANESTETYZM I ANTYESTETYZM}

Na początku warto sprecyzować, co należy rozumieć pod pojęciami panestetyzmu i antyestetyzmu (inaczej antyestetyki), które następnie skonfrontowane zostaną z poglądami i twórczością Lovecrafta. Zagadnienia panestetyzmu i antyestetyki opisuje polska filozof Maria Gołaszewska w Estetyce wspótczesności. Te dwa podejścia do zagadnienia piękna w XX w. stały się przyczyną sporu, w którym uczestniczyli artyści i teoretycy ${ }^{8}$.

Za Marią Gołaszewską można definiować panestetyzm jako „światopogląd i postawę intelektualną uznająca, że piękno stanowi najwyższą wartość w hierar-

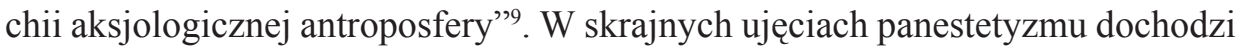
do absolutyzacji piękna. Autorka dodaje, że panestetyzm można też uznać za doktrynę intelektualną opowiadającą się za uznaniem, iż „piękno jest istotnym [...] elementem świata człowieka oraz ma zdolność transcendowania ku innym wysokim wartościom” ${ }^{10}$. Taki sposób myślenia autorka dostrzega w starożytnej filozofii greckiej ${ }^{11}$.

Przykład stanowiska zbliżonego do panestetyzmu w czasach najnowszych Gołaszewska znajduje u Tadeusza Tellera, który jako cechy piękna wymienia: symetrię prawoskrętną; harmonię proporcji kształtów, barw, aromatów, zapachów, ruchów, rytmów; muzyczność; hierarchię oraz majestatyczność ${ }^{12}$.

Antyestetyzm (antyestetyka) to określenie, które pojawiło się w XX w. Według Uniwersalnego stownika języka polskiego antyestetyzm to „pogląd w sztuce i literaturze przeciwstawiający się estetyzmowi, zwalczający estetyzm"13, z kolei antyestetyczny to ,preferujący brzydotę i dysonans, przeciwstawiający się estetyzmowi" ${ }^{14}$. Maria Gołaszewska, charakteryzując antyestetykę, pisze:

\footnotetext{
${ }^{7}$ H.P. Lovecraft, Nadprzyrodzona groza..., s. 497.

${ }^{8}$ M. Gołaszewska, Estetyka współczesności, Kraków 2001, s. 136.

9 Ibidem.

${ }^{10}$ Ibidem.

${ }^{11}$ Ibidem, s. 138.

12 Ibidem.

13 Uniwersalny słownik języka polskiego, red. S. Dubisz, Warszawa 2003, t. 1, s. 96.

${ }^{14}$ Ibidem.
} 
Bliższe znaczenia tego pojęcia były bardzo różnorodne, zawsze jednak chodziło o podanie w wątpliwość krytycznej oceny statusu „estetyczności” [...]. Pytano: czy estetyczność istnieje? czy stanowi warunek dostateczny lub choćby konieczny uzyskiwania wysokiej rangi kulturowej jako moment jednoznacznie, w sposób oczywisty naznaczający człowieczeństwo? [...]

Antyestetyczne koncepcje skierowane były w pierwszym rzędzie ku oczyszczeniu [...] nawarstwionych przez wieki tradycjonalistycznych sposobów myślenia estetycznego, by móc w atmosferze pluralizmu [...] podjąć poszukiwania, zmierzające ku temu, co nowe, ożywcze, autentyczne, dynamiczne ${ }^{15}$.

Maria Gołaszewska dostrzega powiązania między dwudziestowieczną teorią „kryzysu estetyki” a określeniem „śmierci sztuki” użytym w XIX w. przez Heinricha Heinego w związku z zanikiem wiary religijnej, fetyszyzmem industrialnym, spadkiem wiary w sens istnienia ${ }^{16}$ czy teorią Georga W.F. Hegla o powolnym spadku znaczenia kulturowego sztuki w obliczu rozwoju cywilizacji i scjentyfikacji. Polska filozof zauważa, że podobne tezy stawiali Martin Heidegger, dadaiści i konstruktywiści, przy czym dostrzegali oni wartościowość sztuki buntowniczej powstałej w wyniku tych niepokojów. Przytacza też inną wizję Ilji Erenburga, który wiązał nadejście śmierci sztuki z wolnością od zła, dobra, piękna i brzydoty, a przetrwanie sztuki - z ciężarem złudzeń i nadziei ${ }^{17}$.

Podsumowując swoje rozważania, Gołaszewska stwierdza, iż antyestetyka wprowadza w miejsce harmonii horror, brzydotę, pogwałcenie norm i nieporządek $^{18}$.

\section{HOWARD P. LOVECRAFT}

Howard Phillips Lovecraft był amerykańskim pisarzem fantastyki. Urodził się 20 sierpnia 1890 r. w Providence (zmarł 15 marca 1937 r. tamże). Z racji kolonialnych korzeni czuł się arystokratą. Sam uważał się za Anglika i był przeciwnikiem niepodległości Stanów Zjednoczonych. Prowadził dość samotne życie w rodzinnym Providence, nie podejmując pracy zarobkowej, poza poprawianiem na zamówienie cudzych opowiadań. Wyjątkiem od tej reguły był epizodyczny pobyt w Nowym Jorku i krótkotrwałe małżeństwo z Żydówką urodzoną na Ukrainie, Sonią Greene. Utrzymywał jednak znajomość korespondencyjną z wieloma osobami, które zaciekawił swoją twórczością. Jednym z takich znajomych, z którym nigdy nie spotkał się osobiście, był amerykański pisarz August William Derleth. Po śmierci Lovecrafta to właśnie on podjął się zebrania wszystkich rozproszonych dzieł swojego zmarłego mistrza. Założone przez Derletha

${ }^{15}$ M. Gołaszewska, op. cit., s. 139.

16 Ibidem, s. 139. Por. R. Różanowski, Ile estetyki w estetyce...?, „Studia Philosophica Wratislaviensia", vol. 13, fasc. 2 (2018), s. 14-15.

17 M. Gołaszewska, op. cit., s. 139.

18 Ibidem, s. 141. 
wydawnictwo „Arkham House” zaczęło wydawać opowiadania, wiersze, eseje i listy Lovecrafta ${ }^{19}$.

Tłumacz opowiadań Lovecrafta Maciej Płaza podkreśla wpływ atmosfery regionu i domu rodzinnego na konserwatywny światopogląd pisarza i jego ogólną niechęć do współczesności. Wyjątkiem było zainteresowanie odkryciami w obszarach nauk przyrodniczych i ścisłych. Płaza zauważa też, że właśnie w tamtych czasach narodziła się nowoczesna fantastyka, w której tak dobrze odnalazł się Lovecraft, choć odbiło się to negatywnie na warsztacie pisarza i postrzeganiu jego dorobku ${ }^{20}$.

Pisarz uważał się za sceptyka i analityka. W swoim eseju Wyznanie niewiary ${ }^{21}$ thumaczył, jak kształtowały się jego poglądy estetyczne i filozoficzne. Lovecraft już w wieku dziecięcym stał się agnostykiem. Za najbardziej poruszające wydarzenia w swoim życiu uznał odkrycie świata hellenistycznego, poprzez zapoznanie się z mitami greckimi (w wieku 6 lat), oraz zainteresowanie się astronomią (w wieku mniej więcej 12 lat). Ta druga pasja uzmysłowiła mu nieskończoność Wszechświata i ukształtowała przekonanie o znikomym znaczeniu gatunku ludzkiego. Pisarz datował na 17. rok swojego życia moment, w którym uformował swoje pesymistyczne spojrzenie na świat. Błahość wszelkiego istnienia, jak sam określił, imponowała mu, ale i przytłaczała ${ }^{22}$.

W filozofii pisarz był zwolennikiem realizmu i materializmu, a sprzeciwiał się idealizmowi. Wpływ na jego poglądy miały prace Karola Darwina, Ernsta Haeckla i Thomasa H. Huxleya. Niechęć budził u niego jednak realizm w literaturze. W beletrystyce był wielbicielem fantazji, a w poezji i esejach - „eleganckiego formalizmu i konwencjonalności XVIII wieku"23.

I wojna światowa utwierdziła Lovecrafta w jego przekonaniach. Dostrzegał on pustkę we frazesach idealistów, choć przyznawał, że sam takie stosował w celu upiększeń literackich w swoim warsztacie. Dzięki dyskusjom i polemikom z korespondencyjnymi znajomymi usystematyzował swoje poglądy filozoficzne i odrzucił ostatecznie wolną wolę na rzecz determinizmu²4. Uznał, że „,pragnienia, nadzieje oraz wartości ludzkości to zjawiska zupełnie obojętne dla ślepego,

${ }_{19}$ Pełniejsza biografia Lovecrafta znajduje się w: M. Wydmuch, Cień z Providence, [w:] H.P. Lovecraft, Zew Cthulhu, Toruń 2004, s. 5-11; M. Płaza, W przeddzień potwornego zmartwychwstania, [w:] H.P. Lovecraft, Zgroza w Dunwich i inne przerażajace opowieści, wybór, przekład, opracowanie i posłowie M. Płaza, Poznań 2012, s. 762-768; S.T. Joshi, H.P. Lovecraft. Biografia, Poznań 2010.

${ }^{20}$ M. Płaza, op. cit., s. 769-771.

${ }_{21}$ Tyt. oryg. A Confession of Unfaith, wyd. pol. H.P. Lovecraft, Wyznanie niewiary, [w:] idem, Koszmary i fantazje..., s. 232-239.

22 Ibidem, s. 232-237.

${ }^{23}$ Ibidem, s. 237. Por. H.P. Lovecraft, Idealizm i Materializm - refleksja, [w:] idem, Koszmary i fantazje..., s. 243-256.

${ }^{24}$ H.P. Lovecraft, Wyznanie niewiary ..., s. 237-238. 
kosmicznego mechanizmu”25, a szczęście jest tylko etycznym widmem, „którego podobizna w pełni nie ukazuje się nikomu, a po części tylko nielicznym"26.

Lovecraft uważał, że „współczesna nauka okazała się wrogiem sztuki i przyjemności [...], odarła świat z uroku, cudów i wszystkich złudzeń heroizmu, szlachetności i poświęcenia, które tak dumnie prezentowały się w ujęciu romantycznym" ${ }^{27}$. Odkrycia naukowe zniszczyły w ludziach oczytanych czynnik uczuciowy przez rozbicie go na ideę intelektu i impuls zwierzęcia. W opinii Lovecrafta wszystkie wartości zostały przewartościowane przez Friedricha Nietzschego, a następnie masowo zniszczone przez Remy'ego de Gourmonta. Szok wywołany tą wiedzą zaowocował, zdaniem Lovecrafta, powstaniem dziwacznej, niegustownej, buntowniczej oraz chaotycznej literatury T.S. Eliota, D.H. Lawrence'a, Jamesa Joyce'a, Bena Hechta, Aldousa Huxleya i Jamesa Brancha Cabella. Ratunku dla sztuki pisarz upatrywał w zaakceptowaniu faktu, że „całkowita świadomość i prawda same w sobie są bezwartościowe”, wobec czego artysta powinien sam narzucić sobie nowe ograniczenia świadomości. Przy tym zabiegu Lovecraft proponuje zaczerpnięcie ze wzorców płynących ze starożytnych tradycji i odwołanie się do cudów i niewiedzy ${ }^{28}$.

Interesującym zagadnieniem, które warto poruszyć w kontekście stosunku Lovecrafta do sztuki, są jego poglądy na temat ówczesnej poezji. W 1917 r. pisarz utrzymywał, że sztuka ta, w związku z popularnością wiersza wolnego, znajduje się w fazie dekadencji, ale nie uważał tej sytuacji za groźną. Podkreślał, że czym innym jest radykalizm myśli, a czym innym radykalizm formy, a większość wolnych wierszy drukowanych na łamach szanowanych czasopism ma dekadencki charakter tylko pod względem zastosowanej techniki. Według Lovecrafta bardziej utalentowani poeci po krótkotrwałej modzie porzucą radykalną formę i powrócą do „prawdziwej poezji”, bowiem „,nie będą w stanie pokonać naturalnych praw rytmiki w poetyckiej ekspresji" (normalnych rymów i racjonalnego metrum $)^{29}$. Lovecraft przekonywał, że oznaki tego procesu można już zaobserwować, np. w twórczości Anne Tillery Renshaw ${ }^{30}$.

Jako przykład tkwiącej w błędach szkoły vers libre Lovecraft wskazuje Amy Lowell, a jako jej zasadę - rejestrowanie chwilowych nastrojów i emocji, nieważne w jak amorficznej i bezsensownej postaci, nie zważając na to, czy czytelnik będzie w stanie je zrozumieć. Według Lovecrafta takie utwory tworzone są z odrzuceniem tego, co intelektualne, i nie powstają pod wpływem impulsu artystycznego, lecz procesów psychologicznych i emocjonalnych. Lovecraft zaznaczał jednak, że nie mamy do czynienia z upadkiem poezji, gdyż takie dzieła

\footnotetext{
25 Ibidem, s. 239.

${ }^{26}$ Ibidem.

${ }^{27}$ H.P. Lovecraft, Lord Dunsany i jego twórczość, [w:] idem, Koszmary i fantazje..., s. 134.

${ }^{28}$ Ibidem, s. 134-137.

${ }^{29}$ H.P. Lovecraft, Plaga vers libre, [w:] idem, Koszmary i fantazje..., s. 185-186.

${ }^{30}$ Ibidem, s. 186.
} 
nie są związane z liryką. Według niego jest to - obok „futurystycznej” muzyki czy kubizmu - rodzaj dekadencji intelektualnej i estetycznej. Co ważne, Lovecraft był zdania, że może istnieć niemetryczna poezja ,naprawdę poetycka”. Jako przykład wskazywał twórczość Richarda Aldingtona ${ }^{31}$.

Z powyższych poglądów rysuje się obraz Lovecrafta jako konserwatysty. Nie wszystkie jednak elementy tradycji pisarz oceniał pozytywnie. W $1923 \mathrm{r}$. mocno krytykował sztukę epoki wiktoriańskiej. Według Lovecrafta wiktoriański ideał

skaził anglosaską kulturę i doprowadził do powstania mętnej ,,poezji”, trywialnych czułostek i nadętych komunałów; szarej, nudnej prozy pełnej źle umiejscowionego dydaktyzmu i bezbarwnej sztuczności; mocno odrażającego systemu formalnych zachowań, ubioru oraz ozdób oraz, co najgorsze, bluźnierczej dla wszelkiego artyzmu architektury ${ }^{32}$.

Krytykowani przez Lovecrafta poeci doby wiktoriańskiej to m.in. Thomas Babbington Macaulay, Thomas Carlyle, Ralph Waldo Emerson i George Bernard Shaw. Według Lovecrafta rzeczywiste podstawy sztuki są inne niż te wyznaczone w pruderyjnym XIX w. Sztuka dla Lovecrafta jest tworem powstałym z wrażeń, obrazów, uczuć oraz uniesień, musi odznaczać się przenikliwością i pięknem. Jeśli związana jest $\mathrm{z}$ prostymi fantazjami lub stworzona w nieskomplikowanych czasach, może przyjąć nieskomplikowaną postać3 ${ }^{33}$. Inaczej jest, gdy sztuka powstaje w czasach zawiłych: „,wówczas dąży do rozpadu na części, z których każda stanowi zapis ukrytych wrażeń, a które razem tworzą luźną strukturę, wymagającą od odbiorcy wysublimowanej umiejętności przechwycenia i odtworzenia nastroju twórcy" ${ }^{\prime 4}$.

Podobne prawidłowości, według Lovecrafta, dają się zauważyć w całej literaturze. Jako przykłady pisarz wskazuje twórczość uznawanych za romantyków Williama Blake' ${ }^{35}$ oraz słynącego z malowniczych opisów i muzyczności utworów Johna Keatsa ${ }^{36}$, a także francuskich symbolistów. W powyższych rozważaniach nad literaturą Lovecraft powołuje się m.in. na zwolennika estetyzmu Waltera Patera ${ }^{37}$.

Lovecraft w beletrystyce wyodrębniał trzy główne grupy: romantyczną, realistyczną i fantastyczną. Romantyzm identyfikował z czytelnikami, którzy cenią akcję i uczuciowość, a szukając sensacyjnych wydarzeń, akceptują niemożliwe wydarzenia, żądając jednocześnie podłoża realistycznego. Za dominującą Lovecraft uznał drugą szkołę - realizm, dedykowaną osobom, „których intelekt oraz zmysły analityczne przeważają nad skłonnościami do poetyckości oraz

${ }^{31}$ Ibidem, s. 186-187.

${ }^{32}$ H.P. Lovecraft, $W$ gabinecie redaktora, [w:] idem, Koszmary i fantazje..., s. 193.

33 Ibidem, s. 193-194.

${ }^{34}$ Ibidem, s. 194.

${ }^{35}$ William Blake (1757-1827), angielski poeta, malarz i rytownik, prekursor romantyzmu, zob. Encyklopedia literatury światowej, red. J. Maślanka, Kraków 2005, s. 570.

36 John Keats (1795-1821), angielski poeta romantyczny, zob. Ibidem, s. 741.

${ }^{37}$ H.P. Lovecraft, $W$ gabinecie redaktora ..., s. 192-196. 
uczuciowości”38. Za jej zaletę uważał to, że jest bliska życiu, jednocześnie zarzucając, że momentami pogrąża się w pospolitości. W opinii Lovecrafta przedmiotem zainteresowań obydwu tych szkół jest głównie świat obiektywny, przy czym pierwsza szkoła opiera się na emocjach, druga - na rozumie, a obie ignorują wyobraźnię. To właśnie dla zaspokojenia jej potrzeb istnieje trzecia szkoła - fantastyka. Lovecraft przyznaje, że wyobraźnia nie jest tak rozpowszechniona wśród ludzi jak uczucie i rozum, co przekłada się na znikomą popularność fantastyki. Obdarzeni fantazją nie kierują się użytecznością czy przyzwoitością, są mało praktyczni i nierozumiani przez większość ludzi. Jako reprezentantów tej szkoły Lovecraft wymieniał wspomnianego już Williama Blake'a, a także Edgara Allana Poego, Lorda Dunsany i Ambrose'a Bierce'a ${ }^{39}$.

Powodem, dla którego Lovecraft pisał swoje opowiadania, była chęć utrwalenia wrażeń wzbudzanych przez widoki, pomysły, wydarzenia oraz wizje. Wybierał opowiadania grozy ${ }^{40}$, gdyż - jak twierdził - najbardziej odpowiadały jego skłonnościom. Jednym z jego najsilniejszych pragnień było osiagnięcie złudzenia zaburzenia ograniczeń czasu i przestrzeni, a także praw natury, które zniewalają człowieka zaciekawionego nieskończonością kosmosu. Strach jest, zdaniem autora, najsilniejszym uczuciem, które pomaga w tworzeniu przeczących naturze złudzeń. Groza oraz to, co obce, ściśle się ze sobą wiążą. Jak przekonywał, zawsze będzie istniał jakiś procent ludzi odczuwających ciekawość wobec nieznanej przestrzeni i chęć uwolnienia z tego, co rzeczywiste ${ }^{41}$.

W swoich Uwagach na temat pisania weird fiction Lovecraft wskazywał, że opowiadanie niesamowite powinno zawierać pięć wyraźnych elementów: 1) podstawową grozę czy anormalność, np. jakiś stan czy istotę, 2) ogólne skutki aktywności lub działania bezpośrednie elementu grozy, 3) sposób ujawnienia obiektu będącego ucieleśnieniem grozy, 4) rodzaje przerażenia, 5) specyficzne skutki grozy. Lovecraft przestrzegał przed stosowaniem opisów niewyobrażalnych zjawisk jako zwykłych relacji. Postulował staranne utrzymanie realizmu w każdej części utworu, z wyjątkiem opisu wydarzeń niesamowitych. Opisowi wydarzeń muszą towarzyszyć emocje, inaczej wydadzą się one płaskie i nieprzekonujące. W koncepcji Lovecrafta taka uczuciowa obudowa jest najistotniejsza cechą opowiadania i powinna przyćmiewać postacie i wydarzenia. Te muszą być jednak spójne i naturalne, a w zetknięciu z nadnaturalnym elementem bohaterowie powinni wyrażać takie same emocje, jakie wyraziliby w prawdziwym życiu. Lovecraft starał się tworzyć takie poczucie bojaźni lub podziwu, jakie powinien

${ }^{38}$ H.P. Lovecraft, $W$ obronie Dagona, [w:] idem, Koszmary i fantazje..., s. 268.

39 Ibidem, s. 267-268.

${ }^{40} \mathrm{~W}$ oryginale Lovecraft używa sformułowania weird story, które Mateusz Kopacz thumaczy jako „opowiadanie grozy” lub „opowiadanie niesamowite”. Zob. H.P. Lovecraft, Notes on Writing Weird Fiction, http://www.hplovecraft.com/writings/texts/essays/nwwf.aspx (dostęp: 30.03.2019); idem, Uwagi na temat pisania weird fiction, [w:] idem, Koszmary i fantazje..., s. 29, 32.

${ }^{41}$ H.P. Lovecraft, Uwagi na temat pisania weird fiction ..., s. 29-30. 
odczuwać czytelnik. Zgodnie z jego opinią to klimat, a nie akcja, jest najważniejszy w weird fiction ${ }^{42}$.

Lovecraft zdawał sobie sprawę z ograniczeń wybranego przez siebie gatunku. Opowieść niesamowita może stanowić, jego zdaniem, co najwyżej obraz pewnego typu ludzkiego nastroju. Gdy taka opowieść próbuje być czymś więcej, staje się infantylna i nieprzekonująca. Główny nacisk należy więc położyć na subtelną sugestię nastrojów, budującą złudzenie prawdziwości tego, co nierealne. Należy unikać zbyt dużej ilości niewiarygodnych zdarzeń, jeśli nie wnoszą one nic istotnego ${ }^{43}$.

Lovecraft zauważał też, że zaburzenia zasad natury nie powinny przyjmować wyrazistego opisu, dlatego im subtelniej napisane jest opowiadanie, tym bliżej mu do doskonałości. Za najwspanialsze opowiadanie grozy wszech czasów Lovecraft uznawał Wierzby Algernona Blackwooda, w którym groza nie przyjmuje jawnego i widzialnego kształtu. Niestety, jak użalał się, prości czytelnicy i wydawcy tego nie rozumieja. Nie pochwalał jednak nadmiernego niedopowiedzenia, stosowanego przez niewprawionych pisarzy ${ }^{44}$.

W swoich opowiadaniach Lovecraft chętnie opisywał miejsca, które znał, np. bostońską dzielnicę North End w Modelu Pickmana ${ }^{45}$, okolice Benefit Street w Providence w opowiadaniu Przeklęty dom ${ }^{46}$, cmentarz Charter Street Burying Ground w Salem w opowiadaniu Nienazwane ${ }^{47}$. Nie zawsze jednak podawał w utworach ich nazwy, raczej opisywał je jako miejsca fikcyjne ${ }^{48}$.

W kontekście nazewnictwa warto wspomnieć o sposobie tworzenia przez Lovecrafta nazw miejsc i mieszkańców innych planet. Pisarz uważał, że język pozaziemskich bytów, pozbawionych ludzkich narządów mowy, nie powinien przypominać ludzkiego. Wymyślając pozaziemskie nazwy, Lovecraft tworzył różne ich warianty, w zależności od tego, skąd pochodził bohater, który je zapisał lub używał, np. Yog-Sothoth w wersji arabskiej, Yog-Sototl w wersji azteckiej. Jako przykład tego schematu Lovecraft wskazuje wedyjską nazwę Dyaus-Pitar, którą Rzymianie przyjęli jako Jupiter ${ }^{49}$.

Lovecraft usilnie twierdził, że w dziedzinie pisarstwa jest jedynie amatorem, a swojej twórczości nie określał mianem prawdziwej literatury. Zaznaczał też, że nawet gdyby taki poziom osiagną, to byłaby to tylko prosta forma literatury

42 Ibidem, s. 32-33.

${ }^{43}$ Ibidem, s. 33.

${ }^{44}$ H.P. Lovecraft, Do Roberta E. Howarda, 4 października 1930, [w:] idem, Koszmary i fantazje..., s. 34-35.

45 Zob. H.P. Lovecraft, Model Pickmana, [w:] idem, Przyszła na Sarnath zagłada ..., s. 293-309.

${ }^{46}$ Zob. H.P. Lovecraft, Przeklęty dom, [w:] idem, Najlepsze opowiadania, t. 2, Poznań 2008, s. 95-136.

47 Zob. H.P. Lovecraft, Nienazwane, [w:] idem, Droga do szaleństwa, Poznań 2004, s. 200-208.

${ }^{48}$ H.P. Lovecraft, Do Duane'a Rimela, 14 lutego 1934, [w:] idem, Koszmary i fantazje..., s. 72-73.

${ }^{49}$ Ibidem, s. 73-75. 
eskapistycznej. Pisarz miał świadomość znikomej wagi wybranego przez siebie gatunku. Podkreślał jednak, że cechuje go szczerość i prawdziwość, ponieważ poczucie nieznanego jest autentycznym, niezmiennym elementem ludzkiej osobowości. Pisarz przekonywał, że sytuacji tej nie zmienia nowoczesna wiedza, negująca istnienie tego, co nadprzyrodzone. Niezaburzone zostały bowiem, a może nawet wzmocniły się, dwa czynniki. Pierwszy z nich to bunt przeciwko „nieuchronnej tyranii czasu, przestrzeni i praw natury" ${ }^{50}$, który pobudza wyobraźnię do tworzenia hipotez niszczących tę tyranię. Drugi to ciekawość niezgłębionej przestrzeni kosmicznej ${ }^{51}$.

Lovecraft uważał, że literatura niesamowita, aby przetrwać, musi działać w obrębie tych dwóch czynników. Natura człowieka powinna niekiedy tworzyć fantazje, w których zniesione zostają prawa fizyki, a przygoda rozgrywa się „poza granicami narzuconymi przez rzeczywistość”52. Zastrzegał jednak, że w XX w. przy tworzeniu takich fantazji należy zachować większą subtelność niż w przeszłości. Do realizacji tego zadania Lovecraft starał się używać w swoim warsztacie literackim maksimum motywów, które pomagają osiągnąć złudzenie nierzeczywistości, takich jak: ciemność, zachód słońca, sny, mgły, gorączka, szaleństwo, grobowiec, wzgórza, morze, niebo, wicher. Pisarz starał się tworzyć swego rodzaju mitologię „Starszych Sił” i międzygalaktycznych bytów, które na planetach takich jak Ziemia zakładają swoje placówki, a czasem usuwają inne formy życia. Stworzona na użytek fantastyki mitologia ma według Lovecrafta tę zaletę, że można ją przystosować do aktualnych nastrojów czy informacji o świecie. Najlepszym sposobem połączenia takiej mitologii ze światem realnym jest, zdaniem pisarza, subtelne nawiązywanie do starych kultów czy dokumentów, z których wynika, że w dawnych czasach zaobserwowano istnienie zewnętrznych sił. Zwykłe napomknięcie, że takie siły mogą istnieć, to dla Lovecrafta jeden z najbardziej efektywnych punktów kulminacyjnych ${ }^{53}$.

Jak przekonywał Lovecraft, ukazywanie ludziom koncepcji przekraczania granic czasu i przestrzeni w jakiejś mierze zaspokaja ich potrzeby uczuciowe. Niezbędne są tu jednak pewna subtelność i przekonujące pomysły: „Zjawiska nadprzyrodzone powinny być odpowiednio sugerowane, a nie przedstawiane otwarcie, zaś niemożliwe cuda winny w jak największym stopniu składać się z hipotetycznych rozszerzeń rzeczywistości, a nie bezpośrednich i jawnych jej zaprzeczeń" ${ }^{54}$. W opinii Lovecrafta większość pisarzy fantastyki, w tym nawet on sam, niestety zbyt często popuszcza wodze fantazji, co grozi jednostajnością utworu lub komiczną absurdalnością. Podkreślał jednak, że czytelnicy literatury

${ }^{50}$ H.P. Lovecraft, Do Harolda S. Farnese, 22 września 1932, [w:] idem, Koszmary i fantazje..., s. 198.

\footnotetext{
${ }^{51}$ Ibidem, s. 197-198.

52 Ibidem, s. 198.

53 Ibidem, s. 198-199.

${ }^{54}$ Ibidem, s. 200.
} 
fantastycznej różnią się od siebie, co wymaga od każdego pisarza uprzedniego ustalenia swojego kręgu odbiorców ${ }^{55}$.

Znaczenie postaci ludzkich w twórczości Lovecrafta było niewielkie. Pisarz sformułował nawet pogląd, że jego głównymi bohaterami są nie byty organiczne, lecz zjawiska, co tłumaczył faktem, że osoby wywierają na jego wyobraźnię dużo mniejsze wrażenie niż siły bezosobowe. Dlatego też nie były dla niego istotne dialogi. Wyjaśniał to słowami: ,Jeśli doprowadzam bohaterów do rozmowy, to tylko po to, by w ten sposób rejestrować anormalne przemiany ich otoczenia" ${ }^{56}$. Maniera ta była powodem, dla którego Lovecraft odrzucił propozycję napisania dramatu muzycznego, którą złożył mu Harold S. Farnese. Uznał, że nie potrafiłby wykreować „barwnych postaci, niezbędnych do ożywienia dramatu muzycznego" 57 .

Na stawiany Lovecraftowi zarzut, że jego opowiadania nie wzbudzają grozy, odpowiadał, że odmalowywał to, co wyśnił, a reszta należy do odbiorców. Według niego istotą tego, co straszliwe, jest nienaturalnośćs $\mathrm{c}^{58}$. Na przykład w opowiadaniu Dagon $^{59}$ o wynurzającym się morskim dnie straszliwe jest nie samo wynurzające się dno, ale to, że

zostało ono wyniesione [...] przez pewną tajemniczą siłę - i w sposób nienaturalny wybudzone $\mathrm{z}$ odwiecznego snu [...] - oraz że ciagnie się [...] tak daleko, jak tylko sięga wzrok. [Bohater] nie zna więc wielkości terenu - wszystko co z tym obszarem związane, to wątpliwość, cudowność oraz niezwykła tajemnica [...]. Prawdopodobnie najgorsza w tym wszystkim jest samotność na jałowym ogromie ${ }^{60}$.

Powyższe słowa można uznać za kwintesencję lovecraftowskiej wizji samotności człowieka w nieskończonym i nieznanym Wszechświecie.

Pojawiały się też zarzuty, że I wojna światowa wyczerpała możliwości wzbudzania w ludziach strachu przed nowymi koszmarami. Lovecraft odpowiadał, że nigdy nie pisał pod kątem szczególnej epoki, a wojna nie odbiła się na jego pisarstwie. Jego zdaniem koszmary świata realnego nie mają wpływu na dziedzinę grozy nadprzyrodzonej, a umysł ludzki bardziej obawia się tego, co nierealne ${ }^{61}$.

Twórczość Lovecrafta nie była zbyt rozpowszechniona za życia autora. Pisarzowi trudno było znaleźć inne czasopismo do publikacji swoich utworów oprócz magazynu pulpowego „Weird Tales”. Zgodnie z opinią Lovecrafta fikcja pulpowa nie jest dziełem sztuki, bardziej przypomina rzemiosło, a jej twórców nie można identyfikować z prawdziwymi pisarzami. Zastrzegał przy tym, że on sam nie jest zainteresowany tworzeniem konwencjonalnych pulpowych

\footnotetext{
${ }^{55}$ Ibidem, s. 199-200.

56 Ibidem, s. 200.

57 Ibidem.

${ }^{58}$ H.P. Lovecraft, $W$ obronie Dagona ..., s. 270.

59 Zob. H.P. Lovecraft, Dagon, [w:] idem, Zgroza w Dunwich ..., s. 7-15

${ }^{60}$ H.P. Lovecraft, $W$ obronie Dagona ..., s. 270.

${ }^{61}$ Ibidem, s. 272.
} 
utworów, pozbawionych sensu, w celu odniesienia sukcesu w tego typu czasopismach. Prawdziwych artystów w gatunku fantastyki proponował szukać poza czasopismami ${ }^{62}$.

Na marginesie rozważań o poglądach Lovecrafta warto wspomnieć o jego ocenie ilustracji zamieszczanych w czasopiśmie „Weird Tales”. Pisarz zarzucał, że przesiąknięte erotyzmem okładki są kompletnie niezwiązane z treścią opowiadań. Za wartych uwagi ilustratorów „Weird Tales” Lovecraft uznał jedynie Hugh Rakina, Franka Utpatela i Virgila Finlaya. Ubolewał, że dla większości czytelników czasopisma nieznani są John Martin, Sidney H. Sime, Harry Clarke i Arthur Rackman, których uważał za wielkich malarzy fantastyki i makabry ${ }^{63}$.

\section{PODSUMOWANIE}

Podsumowując rozważania na temat poglądów i twórczości Howarda Phillipsa Lovecrafta, należy stwierdzić, że odnaleźć w nich można zarówno elementy panestetyczne, jak i antyestetyczne.

Z panestetyzmem łączył pisarza szacunek, jakim darzył wytwory kultury antycznej, np. mitologię grecką. Opowiadał się za idealizmem w beletrystyce. Był miłośnikiem Oświecenia, które cenił za stylistykę poezji i esejów. To, co najbardziej panestetyczne w poglądach Lovecrafta, to uwielbienie harmonii proporcji kształtów i rytmów, które dostrzegał np. w wierszu sylabicznym i klasycznych metrach, plastyczności i muzyczności wybranych twórców doby romantyzmu czy majestatyczności obrazów. Krytykował związaną z antyestetyką modernistyczną sztukę, jak vers libre, futuryzm, dadaizm czy kubizm.

Z kolei z antyestetyzmem łączy Lovecrafta diagnoza kryzysu sztuki ze względu na postęp cywilizacyjny, który zniszczył uczucia i obalił wszelkie wartości. $\mathrm{W}$ odpowiedzi pisarz proponował jednak inne remedium niż antyesteci, a więc nie sztukę buntownicza, a przedłużenie istnienia piękna, np. w fantazji. Po trosze do antyestetyzmu zbliża go bunt przeciwko literaturze i sztuce epoki wiktoriańskiej - pruderyjnej, sztucznej i wyeksploatowanej, oraz przekonanie o wartościowości sztuki tworzonej w czasach zawiłych i przyjmującej przez to bardziej skomplikowaną postać, z zastrzeżeniem że musi być ona radykalna w treści, a nie tylko w formie.

To, co wiąże Lovecrafta z antyestetyką, to oczywiście jego twórczość, w której odnajdujemy grozę, brzydotę, pogwałcenie norm. Należy tu jednak pamiętać, że Lovecraft pisał przede wszystkim dla siebie samego, a własnej twórczości nie uważał za beletrystykę, lecz rzemiosło, od którego nie potrafił się uwolnić.

${ }^{62}$ H.P. Lovecraft, Do Willisa Conovera, 1 września 1936, [w:] idem, Koszmary i fantazje..., s. 203-204.

${ }^{63}$ Ibidem, s. 204-205. 
Próbując odpowiedzieć na pytanie, czy Howard P. Lovecraft był bardziej panestetą czy antyesteta, można by zaryzykować stwierdzenie, że pisarz był panesteta, lecz niepraktykującym.

\section{BARTŁOMIEJ STEMPIN}

\section{FANTASY, HORROR, PANAESTHETICS AND ANTIAESTHETICS IN THE VIEWS BY HOWARD PHILLIPS LOVECRAFT AND HIS WORKS}

Keywords: fantasy, horror, panaesthetics, antiaesthetics, Howard Phillips Lovecraft

$$
\text { SUMMARY }
$$

The article aims at an insight into the issues of fantasy, horror, panaesthetics and antiaesthetics in the views and works by the early twentieth century American writer, Howard Phillips Lovecraft. Referring to some definitions formulated by various theoreticians, the author of this article firstly explains some basic terms such as: fantasy and horror. Afterwards, he takes a close look into the concepts of panaesthetics and antiaesthetics as well as some other related notions. The essay focuses both on presenting the profile of H.P. Lovecraft and his ideas in the fields of philosophy, arts and literature. Moreover, it intends to outline some advices he made on writing weird stories and building the atmosphere of fear. The author of the article attempts also to characterize H.P. Lovecraft's literarily work in order to juxtapose the writer's views and writing with the ideas behind the concepts of panaesthetics and antiaesthetics. Finally, the author tries to answer the question whether H.P. Lovecraft is to be seen more as a representative of a panaesthetic or rather antiaesthetic viewpoint.

\section{БАРТОЛОМЕЙ СТЕМПИН}

\section{ФАНТАСТИКА, УЖАСЫ, ПАНЭСТЕТИЗМ И АНТИЭСТЕТИЗМ ВО ВЗГЛЯДАХ И ПРОИЗВЕДЕНИЯХ ГОВАРДА ФИЛЛИПСА ЛАВКРАФТА}

Ключевые слова: Фантастика, ужасы, панэстетизм, антиэстетизм, Говард Филлипс Лавкрафт

\section{АННОТАЦИЯ}

Статья представляет собой попытку взглянуть на проблемы фантастики, ужаса, панэстетизма и антиэстетизма во взглядах и творчестве американского писателя в жанре фантастики и ужасов Говарда Филлипса Лавкрафта, писавшего в начале XX века. Автор статьи объясняет такие термины, как фантастика и ужасы, цитируя определения различных теоретиков. Затем он вводит вопросы панэстетизма и антиэстетизма и связанных с ними концепций. В статье представлен портрет Г.Ф. Лавкрафта и его взгляды на философию, искусство и литературу, обращая особое внимание на 
литературу ужасов. Рассмотрены также рекомендации Г.Ф. Лавкрафта, как писать потрясающие истории и создавать в них атмосферу ужаса. Автор статьи пытается охарактеризовать литературное творчество Г.Ф. Лавкрафта, а затем противопоставляет взгляды и произведения писателя положениям панэстетизма и антиэстетизма. Эти размышления резюмируются попыткой ответить на вопрос о том, можно ли говорить о Лавкрафте как о панэстете или антиэстете. 